\title{
The impact of mobilization protocols on the length of postoperative hospitalization among cardiac surgery patients
}

\author{
V. V. Vitomskyi (D)*1,2,A-E, 0. B. Lazarieva (D) 1,A,D,E , E. Yu. Doroshenko (iD) 3,A,D,E,F, \\ M. V. Vitomska (D)1,A,C,D,E, T. M. Kovalenko ${ }^{1}{ }^{1, D, E}, A$. M. Hertsyk (D),D,E,F, S. V. Gavreliuk (D)1,D,E \\ ${ }^{1}$ National University of Ukraine on Physical Education and Sport, Kyiv, Ukraine, ${ }^{2}$ GI "Scientific and Practical Medical Center \\ for Pediatric Cardiology and Cardiac Surgery of the Ministry of Health of Ukraine” (Ukrainian Children's Cardiac Center), Kyiv, Ukraine, \\ ${ }^{3}$ Zaporizhzhia State Medical University, Ukraine, ${ }^{4}$ Ukrainian Catholic University, Lviv, Ukraine
}

A - research concept and design; B - collection and/or assembly of data; C - data analysis and interpretation; D - writing the article; $\mathrm{E}$ - critical revision of the article; $\mathrm{F}$ - final approval of the article

The aim. To determine the impact of implementing the extra early mobilization protocol (EEM) on the length of intensive care unit (LICU) stay and postoperative unit (LPOU) stay and to assess the role of age, heart contractility, functional class and surgical outcomes.

Materials and methods. Participants - adult patients of 2018-2019 with less than 24-hour artificial lung ventilation (ALV). The first group were treated according to the early mobilization protocol (EM, patients of 2018); the second group were treated according to the EEM protocol (patients of 2019). Design: a retrospective analysis. Settings: cardiosurgical unit. Interventions: the major difference is that the resources of patient mobilization team have expanded since 2019 , namely it included a physical therapist, which made it possible to modify the EM protocol (standing on the 2 postoperative day (POD), activation with the help of medical staff, respiratory exercise) to the EEM protocol (standing on the $1 \mathrm{POD}$ following consultation with an anesthesiologist, exercises with a physical therapist, respiratory exercise). The main outcomes: LICU, LPOU and total postoperative hospitalization (LTPO) (number of nights).

Results. There were no differences between the EEM and EM groups in LICU $(3(2 ; 4)$ vs. $2(2 ; 4) ; \mathrm{P}=0.182)$, LPOU $(7(6 ; 10)$ vs. $8(6 ; 10) ; P=0.118)$, LTPO $(10(8 ; 13)$ vs. $10(9 ; 13) ; P=0.308)$. Correlation analysis revealed absence, weak and very weak relations between the LICU, LPOU, LTPO indicators and other criteria, including age, ejection fraction, ALV.

Conclusions. The effectiveness of the EEM protocol seems doubtful to reduce LICU, LPOU, and LTPO as compared to the EM protocol. The obtained results also raise the importance of physical therapist time management.

\section{Вплив протоколів мобілізації на тривалість післяопераційної госпіталізації кардіохірургічних пацієнтів}

\section{В. В. Вітомський, О. Б. Аазарєва, Е. Ю. Аорошенко, М. В. Вітомська, Т. М. Коваленко, А. М. Герцик, С. В. Гаврелюк}

Мета роботи -оцінити вплив запровадження протоколу екстраранньої мобілізації на тривалість перебування у відділенні реанімації (ТПВР) та в післяопераційному відділенні (ТППВ) порівняно зі стандартним протоколом ранньої мобілізації, а також визначити роль віку, скоротливості серця, функціонального класу та показників хірургічного втручання.

Матеріали та методи. Учасники дослідження - пацієнти 2018-2019рр. із тривалістю штучної вентиляції легень менше ніж 24 години. Дизайн - ретроспективний аналіз. Пацієнтів поділили на дві групи: протоколи «ранньої мобілізації» (РМ, пацієнти 2018 р., n = 385) та «екстраранньої мобілізації» (ЕРМ, пацієнти 2019 р., $n=399$ ). Умови - кардіохірургічний стаціонар. Втручання: головна відмінність полягає в тому, що ресурси команди з мобілізації пацієнтів збільшилися з 2019 р., оскільки до неї включений фізичний терапевт, що дало змогу змінити протокол РМ (стояння у 2 післяопераційний день (ПОД), активація за допомогою медичного персоналу, дихальні вправи) на протокол ЕРМ (стояння в 1 ПОД за погодженням з анестезіологом, терапевтичні вправи з фізичним терапевтом, дихальні вправи). Основні результати: ТПВР, ТППВ і тривалість загальної післяопераційної госпіталізації (ТЗПГ) (кількість ночей).

Результати. Не встановили відмінностей між ЕРМ і РМ за ТПВР $(3(2 ; 4)$ проти $2(2 ; 4) ; p=0,182)$, ТППВ (7 (6; 10) проти 8 $(6 ; 10) ; p=0,118)$, ТЗПГ $(10(8 ; 13)$ проти $10(9 ; 13) ; p=0,308)$. Кореляційний аналіз показав відсутність, тільки слабкі та дуже слабкі зв'язки між показниками тривалості госпіталізації та іншими критеріями: віком, балом за Euroscore II, фрракцією викиду, тривалістю штучної вентиляції легень.

Висновки. Ефективність протоколу ЕРМ сумнівна для зменшення ТПВР, ТППВ і ТЗПГ порівняно з РМ. Результати дослідження актуалізують питання раціонального використання часу фізичного терапевта.
Key words: exercise therapy, mobilization, cardiac surgery.

\section{Zaporozhye} medical journa 2021; 23 (2), 259-265

*E-mail: vitomskiyvova@ gmail.com

Ключові слова: фізична терапія, терапевтичні вправи, мобілізація, серцева хірургія.

Запорізький медичний журнал. 2021. T. 23, № 2(125).

C. $259-265$

\section{Влияние протоколов мобилизации на продолжительность послеоперационной госпитализации кардиохирургических пациентов}

\section{В. В. Витомский, Е. Б. Аазарева, Э. Ю. Аорошенко, М. В. Витомская, Т. М. Коваленко, А. М. Герцик, С. В. Гаврелюк}

Цель работы - оценить влияние введения протокола экстраранней мобилизации на длительность пребывания в отделении реанимации (ДПОР) и в послеоперационном отделении (ДППО) по сравнению со стандартным протоколом 
Ключевые слова: физическая

терапия, терапевтические упражнения, мобилизация, сердечная хирургия.

Запорожский медицинский журнал. 2021. T. 23, № 2(125). C. $259-265$

ранней мобилизации, а также установить роль возраста, сократимости сердца, функционального класса, показателей хирургического вмешательства.

Материалы и методы. Участники исследования - пациенты 2018-2019 гг. с длительностью искусственной вентиляции легких менее чем 24 часа. Дизайн - ретроспективный анализ. Пациентов поделили на две группы: протоколы «ранней мобилизации» (РМ, пациенты 2018 г., $\mathrm{n}=385)$ и «экстраранней мобилизации» (ЭРМ, пациенты 2019 г., $\mathrm{n}=399)$. Условия - кардиохирургический стационар. Вмешательство: главное отличие заключается в том, что ресурсы команды по мобилизации пациентов увеличились с 2019 г., а именно к ней подключен физический терапевт, что позволило изменить протокол РМ (стояние во 2 послеоперационный день (ПОД), активация с помощью медицинского персонала, дыхательные упражнения) на протокол ЭРМ (стояние в 1 ПОД по согласованию с анестезиологом, терапевтические упражнения с физическим терапевтом, дыхательные упражнения). Основные результаты: ДПОР, ДППО и продолжительность общей послеоперационной госпитализации (ДОПГ) (количество ночей).

Результаты. Не установили различий между ЭРМ и РМ по ДПОР (3 (2; 4) против 2 (2; 4), p = 0,182), ДППО (7 (6; 10) против $8(6 ; 10) ; p=0,118)$, ДОПГ $(10(8,13)$ против 10 (9; 13); $p=0,308)$. Корреляционный анализ показал отсутствие, только слабые и очень слабые связи между показателями продолжительности госпитализации и другими критериями: возрастом, баллом по Euroscore II, фракцией выброса, продолжительностью искусственной вентиляции легких.

Выводы. Эффективность протокола ЭРМ представляется сомнительной для уменьшения ДПОР, ДППО и ДОПГ по сравнению с РМ. Результаты исследования актуализируют вопрос рационального использования времени физического терапевта.

One of the major factors of iatrogenic harm in patients is hospital-induced immobility, the so-called "pajama paralysis" [1]. Specifics and benefits of mobilizing critically ill patients of intensive care unit (ICU) and surgical patients are important physical therapy issues. Agreat deal of research focuses on the study of an early mobilization impact on ICU patients, including critically ill patients being the most studied population in this regard [2-4]. The barriers to mobilizing critically ill patients include cultural competence in ICU staff and a lack of resources [5].

However, a specialized mobilization team headed by a physical therapist (PT) may be a good option to take the hurdle $[5,6]$. Safety and effectiveness of ICU early mobilization have been proved and strategies to eliminate barriers have been studied in detail $[7,8]$. At the same time, the efficacy and feasibility of early mobilization have been criticized [9].

Historically, cardiac surgery (CS) patients were on bed rest for several postoperative days (POD) in the ICU to prevent complications and promote recovery. Over time, the benefits of early mobilization were acknowledged [10]. CS patients have been found to have a high risk for immobility-related complications [11-13]. CS patient mobilizing practice includes exercises to increase a range of motion, dangling at the bedside and transition to a chair on the operation day, if a patient is able. The first POD entails transferring from the bed to the chair 2-3 times and walking in a room, if possible [10].

Early mobilization is a key part of the post-operative physical therapy performed in the ICU for CS patients [14-16], although the issue of its desirable amount has not yet been resolved.

The obstacles to its implementation require increase in time spent with a patient and a decrease in patient/physical therapist ratio.

\section{Aim}

To determine the impact of implementing the extra early mobilization protocol (EEM) on the length of ICU (LICU) stay and postoperative unit (LPOU) stay and to assess the role of age, heart contractility, functional class and surgical outcomes.

\section{Materials and methods}

Design: retrospective analysis of electronic medical records.

Setting: cardiosurgical unit.

Participants: adult patients who underwent CS in the Department of Congenital and Acquired Heart Defects (Department for Adults) during the period from 2018-2019. The analysis of 784 patients included their age, sex, body weight and length, body surface area (BSA), Euroscore II, cardiac ultrasound findings (ejection fraction, pulmonary hypertension), angina pectoris (functional class, unstable or painless type), comorbidities (arterial hypertension, diabetes mellitus, chronic obstructive pulmonary disease, chronic rheumatic heart disease), heart failure stage, NYHA functional class, cardiac surgery volume and duration, anesthesia, artificial lung ventilation (ALV), cardiopulmonary bypass, aortic compression duration and postoperative arrhythmia. The data of patients with ALV duration of less than 24 hours were analyzed.

The following indicators were studied: the length of ICU stay (LICU, number of nights), postoperative unit stay (LPOU, number of nights) and total postoperative hospital stay (LTPO, number of nights).

Organization of the study. The patients were divided into two groups: patients of the first group were treated according to the early mobilization protocol (EM, patients of 2018), whereas patients of the second group were treated according to the EEM protocol (patients of 2019). The major difference between the groups was the patient mobilization team extension in 2019 including PT, who enabled implementing the EEM protocol.

Interventions. Nurses and cardiologists put the EM protocol into practice through their assistance in mobilization and stimulation of patients' motor activity. The EM patient practice included: 1 - sitting on the bed during ICU stay (1 POD); 2 - upright standing, walking on the spot, walking across a ward in the postoperative unit (usually on the 2 POD if no restrictions existed opposing this); 3 - walking in the hospital corridor (usually on the $3 \mathrm{POD}$ ). If a patient was not transferred to the ward in the postoperative unit on the $2 \mathrm{POD}$, sitting time on the bed was increased, whereas upright standing was not performed in the ICU. 
The EEM patient practice included: 1 - sitting at the side of bed (legs dangling), upright standing on the 1 POD (getting up with assistance and under the PT control, using a rolling walker; as agreed by an anaesthesiologist) and walking on the spot, if feasible; 2 - walking on the spot, walking across a ward in the postoperative unit (usually on the 2 POD unless contraindicated); 3 - walking in the hospital corridor on the 2-3 PODs, doing therapeutic exercises with the PT. If the patient was not transferred to the ward in the postoperative unit on the $2 \mathrm{POD}$, the length of sitting on the bed, standing and walking on the spot was increased, whereas $w$ walking in the hospital corridor was not performed at all. Sessions (about 20 minutes each) with the PT were conducted 2 times a day on the 1-3 PODs, 1 time on the 4-6 PODs. When found appropriate (patient's condition, the need to motivate), the PT could increase the number and length of the sessions. PTs implemented the EEM protocol during the working week, and nurses performed patient mobilization according to the EM protocol on weekends. Before the surgery, the patients were briefly consulted by the PT on the aims and content of the physical therapy and activation algorithm after the surgery.

Physical therapy of both groups included breathing exercises, tapping massage techniques to stimulate mucous clearance and promote motor activity.

Statistical analysis. The materials of the study were processed in a program of statistical analysis IBM SPSS 21. Mathematical processing of the numerical data was fulfilled with the help of variation statistics. The data were assessed for normal distribution using the Shapiro-Wilk (W). But the data mostly did not fit normal distribution. Therefore, nonparametric statistics was used. Wherever the quantitative indicators were not normal, we presented median (Me) and upper/lower quartiles (25\%; $75 \%$ ). Mann-Whitney U tests were used to assess significance of differences. The following criteria were also used: Phi and Cramer's (V), Spearman's rank correlation coefficients.

\section{Results}

The vast majority of indicators were initially tested and found to be non-normally distributed; only BSA indicator was normally distributed in both groups. Body weight and length indicators had the normal distribution only in one of the groups -in the EM $(n=385)$ and the EEM $(n=399)$, respectively. Age and anthropometric indicators did not differ between groups (Table 1). Male-to-female ratio was $63.2 \% / 36.8 \%$ in the EM group and $71.4 \% / 28.6 \%$ in the EEM group, which influenced the statistical difference between the samples. The groups also were statistically different in the Euroscore II indicators. However, the differences revealed could not be considered critical taking into account $\mathrm{Me}(25 \% ; 75 \%)$ indicator of the Euroscore II and the absence of $\mathrm{Me}$ indicator crossing at a 5 point level in both groups (Table 1).

Other specificities of a past medical history and comorbidity were the same for both groups (Table 2).

The frequency of arrhythmias recorded in the database was statistically identical in the EEM and EM groups $8.02 \%$ and $5.71 \%(P=0.199)$, respectively. Cardioversion was performed in $1.75 \%$ and $0.78 \%$ of the patients, respectively $(P=0.222)$. When comparing the EEM and
Table 1. The comparison of main preoperative characteristics and time indicators of surgical interventions according to the U-test, $\mathrm{Me}(25 \% ; 75 \%)$ of the samples

\begin{tabular}{lllll}
\hline Indicators & EEM $(\mathbf{n}=399)$ & EM $(\mathbf{n}=385)$ & $\mathbf{P}$ \\
\hline Age, years & $65(58 ; 72)$ & $64(57 ; 71)$ & 0.315 \\
\hline Sex $(1-\mathrm{M}, 2-\mathrm{F})$ & $1(1 ; 2)$ & $1(1 ; 2)$ & 0.014 \\
\hline Body weight, kg & $80(70 ; 92)$ & $82(72 ; 94)$ & 0.091 \\
\hline Body length, cm & $169(161 ; 175)$ & $170(163 ; 176)$ & 0.060 \\
\hline BSA, kg/m & $1.95(1.80 ; 2.11)$ & $1.99(1.83 ; 2.14)$ & 0.092 \\
\hline Euroscore II, score & $2.31(1.29 ; 5.27)$ & $2.00(1.02 ; 3.85)$ & 0.002 \\
\hline EF, \% & $55(45 ; 60)$ & $55(47 ; 60)$ & 0.154 \\
\hline AH, degree & $2(2 ; 3)$ & $2(1 ; 3)$ & 0.085 \\
\hline NYHA, functional class & $2(2 ; 3)$ & $2(2 ; 3)$ & 0.700 \\
\hline ALV duration, hour & $9(6 ; 13)$ & $8(6 ; 12)$ & 0.066 \\
\hline Operative duration, min. & $345(300 ; 410)$ & $350(300 ; 400)$ & 0.823 \\
\hline Duration of anaesthesia, min. & $420(360 ; 490)$ & $420(360 ; 480)$ & 0.645 \\
\hline CPB duration, min. & $173(138 ; 208)$ & $167(134 ; 205.5)$ & 0.197 \\
\hline Ao compression duration, min. & $117(89.75 ; 145)$ & $109.5(87 ; 143.75)$ & 0.111 \\
\hline
\end{tabular}

EF: ejection fraction; AH: arterial hypertension; ALV: artificial lung ventilation; CPB: cardiopulmonary bypass; Ao: aortic.

Table 2. The comparison of the main sample characteristics at hospitalization according to the Phi and Cramer's (V), \%

\begin{tabular}{l|l|l|l}
\hline Indicators & EEM $(\mathbf{n}=399)$ & EM $(\mathbf{n}=385)$ & $\mathbf{P}$ \\
\hline PH mild / mod. / sev. degree & $13.0 / 20.3 / 14.8$ & $14,8 / 14.3 / 13.8$ & 0.097 \\
\hline APFC 1/2/3/4/ unstable/painless & $0.3 / 17.5 / 24.6 / 3.5 / 1.8 / 0.5$ & $0.3 / 14.8 / 29.6 / 1.8 / 1.8 / 0$ & 0.342 \\
\hline MI & 3 & 1.8 & 0.279 \\
\hline PICS / CS & $22.3 / 1$ & $22.1 / 1$ & 0.996 \\
\hline AH degree 1/2/3 & $6.0 / 41.4 / 34.8$ & $4.2 / 42.3 / 30.1$ & 0.128 \\
\hline HF, degree I/lla/llb/III & $33.6 / 58.9 / 5.5 / 0.3$ & $39 / 56.9 / 2.1 / 0.3$ & 0.101 \\
\hline NYHA, I/II/II/IV functional class & $10.3 / 41.1 / 41.9 / 2.3$ & $11.2 / 35.6 / 43.1 / 2.3$ & 0.265 \\
\hline $\begin{array}{l}\text { Type 1 diabetes mellitus / 2 / } \\
\text { impaired glucose tolerance }\end{array}$ & $0.5 / 17.3 / 1.3$ & $0 / 18.2 / 0$ & 0.077 \\
\hline COPD/CRHD & $3.5 / 7.3$ & & \\
\hline Hydrothorax, left side/right/both & $0.3 / 2.6 / 6.3$ & $4.4 / 5.7$ & $0.515 / 0.378$ \\
\hline
\end{tabular}

mod.: moderate; sev.: severe; MV: mitral valve; AV: aortic valve; TV: tricuspid valve; PH: pulmonary hypertension; APFC: angina pectoris, functional class; MI: myocardial infarction; PICS: postinfarction cardiosclerosis; CS: cardiosclerosis; AH: arterial hypertension; HF: heart failure; COPD: chronic obstructive pulmonary disease; CRHD: chronic rheumatic heart disease.

EM groups, no differences were revealed in LICU (3 (2; 4) vs. $2(2 ; 4) ; P=0,182)$, LPOU $(7(6 ; 10)$ vs. $8(6 ; 10)$; $P=0.118), \operatorname{LTPO}(10(8 ; 13)$ vs. $10(9 ; 13) ; P=0.308)$.

Besides, a correlation analysis revealed absence, low and very low relations between LICU, LPOU, LTPO indicators and criteria that distinguished between the groups of 2019 and 2018. Given that the correlations were similar in the EEM and EM groups, Table 3 demonstrates relations in the total patient sample $(n=784)$. Patient sex had no correlations with LICU, LPOU, or LTPO. Thus, the revealed differences between the EEM and EM groups were not meaningful when comparing LICU, LPOU, and LTPO values in the samples. It should be noted that LICU and LPOU correlation was very weak and inverse (which was seemingly surprising excepting the factors requiring hospital but not ICU stay). LICU did not prolong LPOU in the total sample of CS patients, provided thatALV duration was less than 24 hours.

Taking into account a 5-day working week of PTs, in order to obtain more accurate results, the analysis excluded 2019 patients operated on Friday (or on the day before public holidays) because the PTs could not perform their standing upright on the $1 \mathrm{POD}$. However, this fact did not result in differences between the EEM $(n=329)$ and EM 
Table 3. Main results of the correlation analysis

\begin{tabular}{|c|c|c|c|c|c|c|c|c|c|c|}
\hline Indicators & LICU, nights & $\begin{array}{l}\text { LPOU, } \\
\text { nights }\end{array}$ & LTPO, nights & Age, years & $\begin{array}{l}\text { Euroscore II, } \\
\text { score }\end{array}$ & $\mathrm{EF}, \%$ & PH, intensity & APFC & NYHA & $\begin{array}{l}\text { ALV duration, } \\
\text { hours }\end{array}$ \\
\hline LICU, nights & 1 & $-0.08^{*}$ & $0.24^{\star *}$ & $0.12^{\star *}$ & $0.25^{\star *}$ & $-0.15^{* *}$ & $0.11^{* *}$ & 0.04 & $0.12^{* *}$ & $0.16^{* *}$ \\
\hline LPOU, nights & $-0.08^{*}$ & 1 & $0.92^{\star *}$ & $0.10^{* *}$ & $0.20^{* *}$ & -0.06 & $0.14^{* *}$ & -0.05 & $0.09^{*}$ & $0.14^{* *}$ \\
\hline LTPO, nights & $0.24^{* *}$ & $0.92^{* *}$ & 1 & $0.14^{* *}$ & $0.29^{* *}$ & $-0.12^{* *}$ & $0.20^{* *}$ & -0.04 & $0.14^{* *}$ & $0.19^{* *}$ \\
\hline Age, years & $0.12^{* *}$ & $0.10^{* *}$ & $0.14^{\star \star}$ & 1 & $0.48^{\star *}$ & $-0.14^{* *}$ & 0.07 & $0.19^{\star \star}$ & $0.25^{\star \star}$ & $0.14^{* *}$ \\
\hline Euroscore II, score & $0.25^{\star *}$ & $0.20^{* *}$ & $0.29^{\star *}$ & $0.48^{* *}$ & 1 & $-0.38^{* *}$ & $0.40^{* *}$ & 0.00 & $0.46^{* *}$ & $0.25^{* *}$ \\
\hline$E F, \%$ & $-0.15^{\star *}$ & -0.06 & $-0.12^{* *}$ & $-0.14^{* *}$ & $-0.38^{\star *}$ & 1 & $-0.12^{* *}$ & $-0.13^{* *}$ & $-0.26^{* *}$ & $-0.11^{* *}$ \\
\hline $\mathrm{PH}$, degree & $0.11^{* *}$ & $0.14^{* *}$ & $0.20^{\star \star}$ & 0.07 & $0.40^{\star *}$ & $-0.12^{* *}$ & 1 & $-0.32^{* *}$ & $0.28^{* *}$ & 0.03 \\
\hline APFC & 0.04 & -0.05 & -0.04 & $0.19^{* *}$ & 0.00 & $-0.13^{* *}$ & $-0.32^{* *}$ & 1 & 0.04 & 0.03 \\
\hline NYHA & $0.12^{* *}$ & $0.09^{*}$ & $0.14^{* *}$ & $0.25^{\star *}$ & $0.46^{\star *}$ & $-0.26^{* *}$ & $0.28^{* *}$ & 0.04 & 1 & $0.14^{* *}$ \\
\hline
\end{tabular}

*: statistically significant difference, $\mathrm{P}<0.05 ; * *$ : P $<0.01$; LICU: length of ICU stay; LPOU: length of postoperative unit stay; LTPO: length of total postoperative hospital stay; EF: ejection fraction; PH: pulmonary hypertension; APFC: angina pectoris, functional class; ALV: artificial lung ventilation.

Table 4. The comparison of the main preoperative characteristics and operative time among the CABG patients according to the U-test, Me (25\%; $75 \%)$ indicators

\begin{tabular}{l|l|l|l|}
\hline Indicators & EEM-CABG $(\mathbf{n}=120)$ & EM-CABG $(\mathbf{n}=155)$ & $\mathbf{P}$ \\
\hline Age, years & $65(59 ; 71)$ & $66(60 ; 72)$ & 0.523 \\
\hline Sex $(1-\mathrm{M}, 2-\mathrm{F})$ & $1(1 ; 2)$ & $1(1 ; 1)$ & 0.145 \\
\hline Body weight, $\mathrm{kg}$ & $82(73 ; 93)$ & $86(75 ; 95)$ & 0.157 \\
\hline Body length, sm & $168(161 ; 174)$ & $170(165 ; 175)$ & 0.138 \\
\hline BSA, kg/m² & $1.97(1.84 ; 2.12)$ & $2.03(1.88 ; 2.16)$ & 0.165 \\
\hline Euroscore II, score & $1.51(0.99 ; 2.46)$ & $1.54(0.91 ; 2.97)$ & 0.957 \\
\hline EF, \% & $55(47 ; 58.75)$ & $55(50 ; 59)$ & 0.379 \\
\hline AH, degree & $2(2 ; 3)$ & $2(2 ; 3)$ & 0.406 \\
\hline NYHA, functional class & $2(2 ; 3)$ & $2(2 ; 3)$ & 0.356 \\
\hline ALV duration, hour & $7(6 ; 10)$ & $7(6 ; 11)$ & 0.884 \\
\hline Operative duration, min. & $340(300 ; 390)$ & $360(300 ; 400)$ & 0.164 \\
\hline Duration of anaesthesia, min. & $420(360 ; 460)$ & $435(367.5 ; 490)$ & 0.080 \\
\hline CPB duration, min. & $145(125 ; 169)$ & $147.5(123 ; 173)$ & 0.569 \\
\hline Ao compression duration, min. & $95(74 ; 112)$ & $93(75.5 ; 110.5)$ & 0.922 \\
\hline
\end{tabular}

CABG: coronary artery bypass graft; EF: ejection fraction; AH: arterial hypertension; ALV: artificial lung ventilation; CPB: cardiopulmonary bypass; Ao: aortic.

( $\mathrm{n}=385)$ samples: $\operatorname{LICU}(2(2 ; 4)$ nights vs. 2 (2; 4) nights; $\mathrm{P}=0.987)$, LPOU $(7(6 ; 10)$ vs. $8(6 ; 10) ; \mathrm{P}=0.183)$, LTPO $(10(8 ; 13)$ vs. $10(9 ; 13) ; P=0.311)$.

At the same time, the analysis revealed no differences between the EEM and EM groups in LICU, LPOU, and LTPO when age limits were set for the analysis (over 50, 60, 65, 70 years). This showed that the EEM and EM protocols had equal influence on these indicators regardless of the age. This corresponded to very weak correlations between the age and LICU, LPOU, LTPO (Table 3).

Following the previous exclusion criterion for 2019 patients and considering that the vast majority of patients stayed in the ICU for two nights (the EEM $57.1 \%$ with $\mathrm{n}=329$; the EM $52.5 \%$ with $\mathrm{n}=385$ ), we assessed the impact of the EEM applying on LPOU and LTPO among patients who spent only two nights in the ICU. Such an exclusion revealed significant differences between the EEM $(n=188)$ and EM $(n=202)$ samples: LPOU $(7(6 ; 10)$ vs. 8 (7; 10); $P=0.031)$, LTPO (9 (8; 12) vs. $10(9 ; 12)$; $P=0.031)$. Therefore, we concluded that the EEM protocol had reduced LPOU and, accordingly, LTPO for the patients with ALV of less than 24 hours and a two-night ICU stay after the surgery.

Since patients with coronary artery bypass graft (CABG) alone comprised the majority in the groups, we undertook such analysis algorithm among CABG patients (EEM-CABG and EM-CABG). These samples had the same male-to- female ratio, Euroscore II (Table 4), and other indicators studied in the general groups (Table 2). A comparison between EEM-CABG $(n=120)$ and EM-CABG $(n=155)$ groups revealed no differences in LICU $(2(2 ; 3)$ vs. 2 (2; $3) ; P=0.780)$, LPOU (7 (5); 8.75) vs. 7 (6;9); $P=0.119$; LTPO (9 (8; 11) vs. 10(8; 12); P = 0.147).

The analysis excluded the EEM patients who were operated on Friday (or on the day before public holidays) in the same way as the analysis algorithm for the general groups. However, this did not find differences between the EEM $(n=101)$ and EM $(n=55)$ patients. The next step (including patients with 2 night-LICU) did not result in the EEM $(n=66)$ superiority over the EM $(n=81)$ patients: LPOU (7 (6; 9) vs. $7.0(6.5 ; 10.0) ; P=0.102)$, $\operatorname{LTPO}(9(8 ; 11)$ vs. $9.0(8.5 ; 12.0) ; \mathrm{P}=0.102)$. Considering the last results obtained and the previous the EEM superiority (Friday excluding and 2 night-LICU filters $-n=188$ ) over the EEM (LICU = 2 filter $-\mathrm{n}=202$ ), we came to the conclusion that there was a group or groups of patients (with 2 night-LICU filter), in whom the EEM protocol reduced LPOU (and LTPO as a result), but these groups did not include patients with CABG alone.

This warrants a more detailed identification of patient groups where the EEM protocol reduced LPOU and indirectly LTPO. Accordingly, the analysis included other patients (the EEM group with Friday excluding and 2 night-LICU filters; the EEM group with 2 night-LICU filter) grouped by the type of CS interventions (distinct or combined) to identify the EEM patients benefits. However, the analysis did not identify such groups of patients.

Thus, we can summarize that the comparison between the EEM and EM patients using exclusion factors (Friday excluding and 2 night-LICU filters for the EEM patients ( $n=188) ; 2$ night-LICU filter $(n=202)$ for the EM patients) revealed the statistically significant positive impact of the EEM protocol primarily on LPOU and indirectly on LTPO. However, this difference lost its significance when these groups were divided by the type of CS interventions due to the decrease in the number of patients in the groups and the increase in the difference threshold, which was necessary to detect the statistical difference.

\section{Discussion}

The PT's role is evidently important in improving the postoperative management of recovery processes in patients and their faster mobilization based on the EEM protocol. 
However, the effectiveness of the EEM protocol seems doubtful in terms of reducing LICU, LPOU, and LTPO as compared to the standardized the EM protocol.

The results obtained actualize the issue of rational using PT time, since the assistance of a patient in standing upright requires a considerable amount of time in addition to overcoming and taking into account many barriers - wires, catheters, drainages.

The analysis confirmed the EEM protocol security. It did not reveal any critical cases leading to falls and traumas or necessity of additional surgery, which proved consistent cooperation of PTs and anesthesiologists in addressing the possibility of patient standing upright in the ICU. This confirmed safety and feasibility of early mobilization of critical and elderly patients in the ICU [7,17-19].

At the same time, results revealed very weak correlations between age and LICU, LPOU and LTPO indicators (Table 3) and no differences between the EEM and EM groups in LICU, LPOU, and LTPO indicators when setting the age limits for the analysis (over 50, 60, 65, 70 years), which proved the EEM protocol sufficiency regardless of patient's age.

Similar to this study, the work of S. Floyd et al. [11] aimed to determine the impact of progressive mobility protocol in cardiovascular ICU, particularly on LICU, LTPO. The researchers did not mention the difference, but for some reason emphasized clinical significance and cost savings of the implemented progressive mobility. At the same time, the analysis of this work showed large LICU and LTPO ranges with small samples, which suggests incorrect criteria of patient selection.

Interestingly, Dubb et al. [7] share our opinion that additional specialists including one PT were involved to implement the EM protocol and overcome barriers. This confirms the relevance of PTs involvement in the ICU. At the same time, PTs mobilized critically ill patients to higher levels compared with nurses [3].

Systematic review of P. M. R. Santos et al. [20] provided evidence of early mobilization impact after CS interventions to prevent postoperative complications and reduce LTPO. The authors [20] identified a variety of methods used for mobilization, as well as the periods considered as early. At the same time, P. M. R. Santos noted that mobilization groups had better results than non-intervention groups and, as a rule, these advantages did not differ among intervention groups (no superiority of the EEM group over the EM group was revealed in this study as well). The researchers failed to perform meta-analysis due to variability of interventions suggested as early mobilization.

In this respect, the conclusion of T. Castelino et al. [21] should be also mentioned: "Few comparative studies have evaluated the impact of early mobilization protocols on outcomes after abdominal and thoracic surgery. The quality of these studies was poor and the results were conflicting. Although bed rest is harmful, there is little evidence available to guide clinicians in effective early mobilization protocols that increase mobilization and improve outcomes".

A recent study has revealed that patients in the early mobilization group had shorter duration of hospitalization after CS [22].

Early mobilization of CS patients is obviously very important in general, but in some studies, this mobilization was even earlier than it was in the EEM group analyzed in the current study. For instance, J. K. Brown et al. [23] state: "It is important to emphasize to patients the importance of an early mobilization plan with daily goals for time out of bed and distance started as soon as the day of surgery". It seems interesting that the importance of being out of bed and distance walked begins as early as the day of the surgery. However, the following factors should be considered as well: surgery start time (8:00 AM, 9:00 AM, or 2:00 PM), duration of surgery, anesthesia and ALV, the duration of PT working day, the patient status.

Brown J. K. [23], on the other hand, showed the absence of Enhanced Recovery After Surgery (ERAS) impact on the length of hospital stay with reference to I. O. Fleming et al. [24]. A significant number of the physical therapy protocols [25-27] reported mobilization from the bed on the 1 $\mathrm{POD}$, walking within the ward on the $2 \mathrm{POD}$, walking in the corridor on the $3 \mathrm{POD}$, but there are studies indicating that standing upright was normally performed on the $3 \mathrm{POD}$ $[28,29]$. PT survey [30] also confirmed that there were slight variations in mobilization supervised by PTs following CS.

It has long been noted: "Lastly, it is important to realize that early extubation does not necessarily mean early intensive care unit or hospital discharge" [31]. It should be realized that physical therapy and standing upright on the $1 \mathrm{POD}$ do not guarantee reduction in LICU, LPOU and LTPO. There are many factors that make these terms prolonged, namely the results of blood tests, rhythm disturbances, pericarditis, dysfunction of kidney and other internal organs, the need to determine the optimal dose of pharmacological drugs.

\section{Conclusions}

1. The EEM protocol implementation did not reduce the length of stay in the intensive care unit and postoperative unit, as well as the total length of hospital stay as compared to the standardized EM protocol.

2. The studied approaches to early mobilization were equally effective, despite the fact that the EEM protocol was implemented by physical therapists, and the EM protocol by nurses and cardiologists. Correlation analysis revealed absence, weak and very weak relations between the LICU, LPOU, LTPO indicators and age, ejection fraction, ALV.

Study limitations. The study failed to conduct a fullscale examination of the postoperative condition severity in patients. Taking into account a quite large number of patients in the groups, exclusion criteria (ALV duration of less than 24 hours) and the fact that the examined patients were enrolled from two consecutive years, the possibility of the groups to differ in postoperative severity indicators was minimized.

Prospects for future research. Taking into account that mobilization and walking are performed on the day of surgery in some studies, these factors raise the following questions. If surgery starts in the morning, should PT ambulate patients, operated on the same day, every day after 3:00 PM? If surgery starts in the afternoon, when should PT perform mobilization? Will transition to the chair, sitting and walking be maximally aidless on the day of the surgery? Will PT perform it instead of the patient? Will patient and PT be willing for such mobilization on the day of surgery? Will the patient remember any physical therapy goals if he/she has just recovered from anesthesia and just wants to sleep 
or drink? What percentage of anaesthesiologists, cardiologists, and other staff members will consider such activation rational? Is it possibly better to wait a day or even two? How much time does this mobilization require on the day of surgery? Is it possible to use this time more rationally?

There is the need to study the EEM protocol impact on the dynamic of strength, stamina, endurance, external respiration function, and satisfaction with physical therapy in postoperative patients.

Conflicts of interest: authors have no conflict of interest to declare. Конфлікт інтересів: віАсутній.

НаАійшла Ао редакції / Received: 07.10.2020

Після Аоопрацювання / Revised: 24.11.2020

Прийнято Ао Аруку / Accepted: 02.12.2020

Information about authors:

Vitomskyi V. V., PhD, Lecturer of the Department of Physical Therapy and Ergotherapy, National University of Ukraine on Physical Education and Sport; Physical therapist, GI "Scientific and Practical Medical Center for Pediatric Cardiology and Cardiac Surgery of the Ministry of Health of Ukraine" (Ukrainian Children's Cardiac Center), Kyiv, Ukraine.

ORCID ID: 0000-0002-4582-6004

Lazarieva 0. B., PhD, DSc, Professor, Head of the Department of Physical Therapy and Ergotherapy, National University of Ukraine on Physical Education and Sport, Kyiv.

ORCID ID: 0000-0002-7435-2127

Doroshenko E. Yu., PhD, DSc, Professor of the Department of Physical Rehabilitation, Sports Medicine, Physical Training and Health, Zaporizhzhia State Medical University, Ukraine.

ORCID ID: 0000-0001-7642-531X

Vitomska M. V., Lecturer of the Department of Physical Therapy and Ergotherapy, Postgraduate student of the Department of Physical Therapy and Ergotherapy, National University of Ukraine on Physical Education and Sport, Kyiv, Ukraine.

ORCID ID: 0000-0002-5163-3954

Kovalenko T. M., MD, PhD, Associate Professor of the Department of Physical Therapy and Ergotherapy, National University of Ukraine on Physical Education and Sport, Kyiv, Ukraine. ORCID ID: 0000-0001-7999-7066

Hertsyk A. M., PhD, DSc, Professor of the Department of Physical Therapy and Ergotherapy, Ukrainian Catholic University, Lviv Ukraine.

ORCID ID: 0000-0003-1764-5625

Gavreliuk S. V., MD, PhD, Associate Professor of the Department of Physical Therapy and Ergotherapy, National University of Ukraine on Physical Education and Sport, Kyiv, Ukraine. ORCID ID: 0000-0002-1127-6972

\section{Відомості про авторів:}

Вітомський В. В., канА. наук з фізичного виховання та спорту, викиадач каф. фізичної терапії та ерготерапії, Національний університет фізичного виховання і спорту України; фахівець із фізичної реабімітації, АУ «Науково-практичний медичний центр дитячої кардіології та кардіохірургії М03 України", м. Київ.

Аазарева О. Б., А-р наук з фізичного виховання та спорту, професор, зав. каф. фізичної терапії та ерготерапії, Національний університет фізичного виховання і спорту України, м. Київ. Аорошенко Е. Ю., А-р наук з фізичного виховання та спорту, професор каф. фізичної реабілітації, спортивної меАицини, фізичного виховання і здоров'я, Запорізький Аержавний медичний університет, Україна.

Вітомська М. В., викладач каф. фізичної терапії та ерготерапії, аспірант каф. фізичної терапії та ерготерапії, Національний університет фізичного виховання і спорту України, м. Київ, Коваленко Т. М., канА. меА. наук, Аоцент каф. фізичної терапії та ерготерапії, Національний університет фізичного виховання і спорту України, м. Київ.
Герцик А. М., А-р наук з фізичного виховання та спорту, Аоцент, професор каф. фізичної терапії та ерготерапії, Український католицький університет, м. Аьвів, Україна.

Гаврелюк С. В., канА. меА. наук, доцент каф. фізичної терапії та ерготерапії, Національний університет фізичного виховання і спорту України, м. Київ.

\section{Сведения об авторах}

Витомский В. В., канА. наук по физическому воспитанию и спорту, преподаватель каф. физической терапии и эрготерапии, Национальный университет физического воспитания и спорта Украины; специалист по физической реабилитации, ГУ «Научно-практический меАицинский центр Аетской кардиологии и кардиохирургии МЗ Украины", г. Киев. ^азарева Е. Б., А-р наук по физическому воспитанию и спорту, профессор, зав. каф. физической терапии и эрготерапии, Национальный университет физического воспитания и спорта Украины, г. Киев.

Аорошенко Э. Ю., А-р наук по физическому воспитанию и спорту, профессор каф. физической реабилитации, спортивной медицины, физического воспитания и зАоровья, Запорожский государственный медицинский университет, Украина. Витомская М. В., преподаватель каф. физической терапии и эрготерапии, аспирант каф. физической терапии и эрготерапии, Национальный университет физического воспитания и спорта Украины, г. Киев.

Коваленко Т. Н., канА. меА. наук, Аоцент каф. физической терапии и эрготерапии, Национальный университет физического воспитания и спорта Украины, г. Киев. Герцик А. М., А-р наук по физическому воспитанию и спорту, Аоцент, профессор каф. физической терапии и эрготерапии, Украинский католический университет, г. ^ьвов, Україна. Гаврелюк С. В., канА. меА. наук, Аоцент каф. физической терапии и эрготерапии, Национальный университет физического воспитания и спорта Украины, г. Киев.

\section{References}

[1] Surkan, M. J., \& Gibson, W. (2018). Interventions to Mobilize Elderly Patients and Reduce Length of Hospital Stay. Canadian Journal of Cardiology, 34(7), 881-888. https://doi.org/10.1016/j.cjca.2018.04.033

[2] Adler, J., \& Malone, D. (2012). Early Mobilization in the Intensive Care Unit: A Systematic Review. Cardiopulmonary Physical Therapy Journal, 23(1), 5-13.

[3] Garzon-Serrano, J., Ryan, C., Waak, K., Hirschberg, R., Tully, S., Bittner, E. A., Chipman, D. W., Schmidt, U., Kasotakis, G., Benjamin, J. Zafonte, R., \& Eikermann, M. (2011). Early mobilization in critically ill patients: patients' mobilization level depends on health care provider's profession. PM\&R, 3(4), 307-313. https://doi.org/10.1016/i.pmri.2010.12.022

[4] Hanekom, S., Gosselink, R., Dean, E., van Aswegen, H., Roos, R., Ambrosino, N., \& Louw, Q. (2011). The development of a clinical management algorithm for early physical activity and mobilization of critically ill patients: synthesis of evidence and expert opinion and its translation into practice. Clinical Rehabilitation, 25(9), 771-787. https:// doi.org/10.1177/0269215510397677

[5] Barber, E. A., Everard, T., Holland, A. E., Tipping, C., Bradley, S. J., \& Hodgson, C. L. (2015). Barriers and facilitators to early mobilisation in Intensive Care: A qualitative study. Australian Critical Care, 28(4) 177-182. https://doi.org/10.1016/i.aucc.2014.11.001

[6] Teves, C. (2017). Improving Patient Outcomes: Early Mobilization of Intensive Care Patients. Honors College Theses, 26. http://scholarworks.umb.edu/honors theses/26

[7] Dubb, R., Nydahl, P., Hermes, C., Schwabbauer, N., Toonstra, A. Parker, A. M., Kaltwasser, A., \& Needham, D. M. (2016). Barriers and Strategies for Early Mobilization of Patients in Intensive Care Units. Annals of the American Thoracic Society, 13(5), 724-730. https://doi. org/10.1513/AnnalsATS.201509-586CME

[8] Sommers, J., Engelbert, R. H., Dettling-lhnenfeldt, D., Gosselink, R. Spronk, P. E., Nollet, F., \& van der Schaaf, M. (2015). Physiotherapy in the intensive care unit: an evidence-based, expert driven, practica statement and rehabilitation recommendations. Clinical Rehabilitation, 29(11), 1051-1063. https://doi.org/10.1177/0269215514567156

[9] Callahan, L. A., \& Supinski, G. S. (2016). Early Mobilization in the ICU: Help or Hype?* Critical Care Medicine, 44(6), 1239-1240. https://doi. org/10.1097/CCM.0000000000001733

[10] Freeman, R., \& Maley, K. (2013). Mobilization of Intensive Care Cardiac Surgery Patients on Mechanical Circulatory Support. Critical Care Nursing Quarterly, 36(1), 73-88. https://doi.org/10.1097/CNQ. $\underline{0 \mathrm{~b} 013 \mathrm{e} 31827532 \mathrm{c} 3}$ 
[11] Floyd, S., Craig, S. W., Topley, D., \& Tullmann, D. (2016). Evaluation of a Progressive Mobility Protocol in Postoperative Cardiothoracic Surgical Patients. Dimensions of Critical Care Nursing, 35(5), 277-282. https:/l doi.org/10.1097/DCC.0000000000000197

[12] Vitomskyi, V. V., \& Al-Hawamdeh, K. M. (2020). Rol respiratornoi fizychnoi terapii u vidnovnomu likuvanni patsiientiv pislia kardiokhirurhichnykh vtruchan [The Role of Respiratory Physical Therapy in the Rehabilitation of Patients after Cardiac Surgery]. Ukrainskyi zhurnal medytsyny, biolohii ta sportu, 5(4), 17-25. https://doi.org/10.26693/ imbs05.04.017 [in Ukrainian]

[13] Vitomskiy, V., Kormiltsev, V., Hruzevych, I., Salnykova, S., Shevchuk, Yu., \& Yakusheva, Yu. (2018). Features of the physical development of children with functionally single heart ventricle as a basis of the physical rehabilitation technology after a hemodynamic correction. Journal of Physical Education and Sport, 18(Suppl. 1), 421-424. https://doi.org/10.7752/jpes.2018.s159

[14] Gama Lordello, G. G., Gonçalves Gama, G. G., Lago Rosier, G., Viana, P., Correia, L. C., \& Fonteles Ritt, L. E. (2020). Effects of cycle ergometer use in early mobilization following cardiac surgery: a randomized controlled trial. Clinical Rehabilitation, 34(4), 450-459. https:// doi.org/10.1177/0269215520901763

[15] Vitomskyi, V. (2020). The impact of mobilization and other factors on pleural effusion in patients undergoing cardiac surgical procedures. Journal of Physical Education and Sport, 20(Suppl. 3), 2167-2173. https://doi.org/10.7752/jpes.2020.s3291

[16] Vitomskyi, V. V. (2020). Theoretical model of sternum external fixation functioning in physical therapy of patients following cardiac surgery via sternotomy. Art of Medicine, (3), 203-209. https://doi.org/10.21802/ artm.2020.3.15.203

[17] Bourdin, G., Barbier, J., Burlem, J. -F., Durante, G., Passant, S., Vincent, B., Badet, M., Bayle, F., Richard, J. -C., \& Guérin, C. (2010). The Feasibility of Early Physical Activity in Intensive Care Unit Patients: A Prospective Observational One-Center Study. Respiratory Care, 55(4), 400-407. http://rc.rcjournal.com/content/55/4/400. short

[18] Nakamura, K., Nakamura, E., Niina, K., \& Kojima, K. (2010). Outcome after valve surgery in octogenarians and efficacy of early mobilization with early cardiac rehabilitation. General Thoracic and Cardiovascular Surgery, 58(12), 606-611. https://doi.org/10.1007/s11748-010-0665-0

[19] Vollman, K. M. (2013). Understanding Critically III Patients Hemodynamic Response to Mobilization: Using the Evidence to Make It Safe and Feasible. Critical Care Nursing Quarterly, 36(1), 17-27. https://doi. org/10.1097/CNQ.0b013e3182750767

[20] Santos, P. M. R., Ricci, N. A., Suster, É. A. B., Paisani, D. M., \& Chiavegato, L. D. (2017). Effects of early mobilisation in patients after cardiac surgery: a systematic review. Physiotherapy, 103(1), 1-12. https://doi. org/10.1016/i.physio.2016.08.003

[21] Castelino, T., Fiore, J. F., Jr, Niculiseanu, P., Landry, T., Augustin, B., \& Feldman, L. S. (2016). The effect of early mobilization protocols on postoperative outcomes following abdominal and thoracic surgery: A systematic review. Surgery, 159(4), 991-1003. https://doi.org/10.1016/i. $\underline{\text { surg.2015.11.029 }}$

[22] Yayla, A., \& Özer, N. (2019). Effects of early mobilization protocol performed after cardiac surgery on patient care outcomes. International Journal of Nursing Practice, 25(6), Article e12784. https://doi. org/10.1111/ijn.12784

[23] Brown, J. K., Singh, K., Dumitru, R., Chan, E., \& Kim, M. P. (2018). The Benefits of Enhanced Recovery After Surgery Programs and Their Application in Cardiothoracic Surgery. Methodist Debakey Cardiovascular Journal, 14(2), 77-88. https://doi.org/10.14797/mdcj-14-2-77

[24] Fleming, I. O., Garratt, C., Guha, R., Desai, J., Chaubey, S., Wang, Y., Leonard, S., \& Kunst, G. (2016). Aggregation of Marginal Gains in Cardiac Surgery: Feasibility of a Perioperative Care Bundle for Enhanced Recovery in Cardiac Surgical Patients. Journal of Cardiothoracic and Vascular Anesthesia, 30(3), 665-670. https://doi.org/10.1053/j.jvca.2016.01.017

[25] Moreno, A. M., Castro, R. R. Sorares, P. P., Sant' Anna, M., Cravo, S. L., \& Nóbrega, A. C. (2011). Longitudinal evaluation the pulmonary function of the pre and postoperative periods in the coronary artery bypass graft surgery of patients treated with a physiotherapy protocol. Journal of Cardiothoracic Surgery, 6, Article 62. https://doi. org/10.1186/1749-8090-6-62

[26] Urell, C., Emtner, M., Hedenstrom, H., \& Westerdahl, E. (2016) Respiratory muscle strength is not decreased in patients undergoing cardiac surgery. Journal of Cardiothoracic Surgery, 11, 41. https://doi. org/10.1186/s13019-016-0433-z

[27] Westerdahl, E., Lindmark, B., Almgren, S. O., \& Tenling, A. (2001). Chest physiotherapy after coronary artery bypass graft surgery - a comparison of three different deep breathing techniques. Journal of Rehabilitation Medicine, 33(2), 79-84. https://doi.org/10.1080/165019701750098920

[28] Crowe, J. M., \& Bradley, C. A. (1997). The Effectiveness of Incentive Spirometry With Physical Therapy for High-Risk Patients After Coronary Artery Bypass Surgery. Physical Therapy, 77(3), 260-268. https://doi. org/10.1093/pti/77.3.260
[29] Moradian, S. T., Najafloo, M., Mahmoudi, H., \& Ghiasi, M. S. (2017). Early mobilization reduces the atelectasis and pleural effusion in patients undergoing coronary artery bypass graft surgery: A randomized clinical trial. Journal of Vascular Nursing, 35(3), 141-145. https://doi. org/10.1016/j.jvn.2017.02.001

[30] Westerdahl, E., \& Möller, M. (2010). Physiotherapy-supervised mobilization and exercise following cardiac surgery: a national questionnaire survey in Sweden. Journal of Cardiothoracic Surgery, 5, Article 67. https://doi.org/10.1186/1749-8090-5-67

[31] Cheng, D. C. (1998). Fast-track cardiac surgery: economic implications in postoperative care. Journal of Cardiothoracic and Vascular Anesthesia, 12(1), 72-79. https://doi.org/10.1016/s1053-0770(98)90061-1 